\title{
OFICINAS DE GEOCIÊNCIAS COMO ESTRATÉGIA DE EDUCAÇÃO AMBIENTAL EM ESCOLAS DA REDE MUNICIPAL DE SÃO CARLOS (SP)
}

\author{
Raimunda Gomes Silva Soares ${ }^{1}$ \\ Nícolas Guerra Rodrigues Tão \\ Alexandre da Silva Faustino ${ }^{3}$ \\ Marcilene Dantas Ferreira ${ }^{4}$
}

Resumo: A compreensão dos processos naturais e da sua relação com o mundo moderno é condição fundamental para a conscientização e o desenvolvimento das práticas de sustentabilidade. Este trabalho visa aplicar os conhecimentos das geociências no desenvolvimento de práticas de educação ambiental através de oficinas teórico-práticas para alunos e professores em escolas na rede pública da cidade de São Carlos - São Paulo. Nas oficinas, questões ambientais são exploradas ao longo de conceitualizações expositivas e atividades práticas. Até o momento foram realizadas duas oficinas sobre minerais e rochas além de uma oficina sobre solos. Os resultados indicam uma dificuldade de assimilação dos conceitos, mas a maioria dos alunos pode entender as problemáticas apresentadas e sugeriu práticas mais sustentáveis para o seu cotidiano.

Palavras-chave: Processos Naturais; Sensibilização Ambiental; Práticas em Sustentabilidade.

\footnotetext{
${ }^{1}$ Universidade Federal de São Carlos. E-mail: raigomessoares@yahoo.com.br

${ }^{2}$ Universidade Federal de São Carlos. E-mail: nicolas.tao@hotmail.com

${ }^{3}$ Universidade Federal de São Carlos. E-mail: alexandre.mog@gmail.com

${ }^{4}$ Universidade Federal de São Carlos. E-mail: marcilene.dantas@gmail.com
} 


\section{Introdução}

Entende-se a educação ambiental não como uma teoria a ser seguida, mas um ponto de partida, uma forma de aprender e saber olhar o ambiente, sentir, viver e interagir, baseada nos princípios de "participação, pensamento crítico-reflexivo, sustentabilidade, ecologia de saberes, responsabilidade, continuidade, igualdade, conscientização, coletividade, emancipação e transformação social' (GONZALES, 2007; BRANDÃO, 2007).

Para isso em sua prática faz-se necessário uma visão holística do ambiente, trabalhada sob a lógica da transdiciplinaridade, abrangendo conhecimento de várias ciências. E neste sentido as geociências, antes lembradas apenas como importantes na exploração dos recursos naturais, hoje se apresentam como parte fundamental deste processo, uma vez que seus conhecimentos permitem uma visão integrada da dinâmica da Terra e o entendimento dos processos naturais que sustentam o modo de vida atual, bem como a consciência da capacidade de reposição desses recursos e dos impactos de sua utilização.

Tal visão é ratificada por Compiani e Gonçalves (1996), quando afirmam que o conhecimento do sistema terra fornecido pelas geociências não contribui apenas para a apropriação material do planeta, possibilitando a sobrevivência da humanidade, mas também discute e fundamenta valores estéticos, éticos, morais e ideológicos e analisa as consequências sociais e ambientais da alteração da terra, permitindo com isso o desenvolvimento de atitudes que contribuam com a valorização dos benefícios ambientais, assim como tomar consciência das limitações e danos derivados das aplicações desse conhecimento.

No entanto, o processo de disseminação desses conhecimentos tem como desafio o nível de abstração necessário para se entender os inúmeros mecanismos complexos que interagem no ambiente, sendo que os mesmos são de tal forma interdependentes que uma visão fragmentada impossibilita a real compreensão de sua magnitude. Considera-se ainda, ser o aprendizado efetivo desses conteúdos específicos das geociências dependentes na maioria dos casos da utilização de recursos que aproximem o aluno dos conteúdos abordados e possibilitem a formação de analogias com algo comum aos mesmos. Faz-se necessário também uma abordagem que instigue a curiosidade, a dúvida e a busca pelo saber; que considere as experiências individuais, afim de que por meio da reflexão e unificação de saberes forme-se um conhecimento coletivo e contextualizado.

Segundo os Parâmetros Curriculares Nacionais - PCN (BRASIL, 2002), é preciso selecionar conteúdos e escolher metodologias coerentes com nossas intenções educativas. Elas incluem compreender a natureza como uma intrincada rede de relações, um todo dinâmico, do qual o ser humano é parte integrante, com ela interage, dela depende e nela interfere, reduzindo seu grau de dependência, mas jamais sendo independente. 
Partindo-se dessa indicação, os conhecimentos advindos das geociências se apresentam como o cenário ideal para a disseminação das práticas de Educação Ambiental, pois, como indica Carneiro et al. (2007), a compreensão dos processos naturais e da interação entre estes e o modo de vida moderno é condição fundamental para que haja a conscientização necessária para o desenvolvimento das práticas de sustentabilidade.

Tal fato tem sido abordado em diversos estudos que analisaram o papel do ensino das geociências como uma estratégia de educação ambiental, entre os quais se destaca o de Biondi e Falkowski (2009), que fizeram uma análise de oficinas de educação ambiental com o tema solos, segundo os autores um assunto fundamental, porém pouco abordado pela educação formal. Os autores utilizaram como estratégia central a construção de mapas mentais feitos antes e depois da explanação dos conceitos e concluíram que houve um acréscimo do conhecimento sobre essa temática bem como sensibilização sobre a necessidade de conservação.

Bacci (2009) afirma sobre a contribuição do conhecimento geológico para a educação ambiental. Em seu artigo a autora defende o conhecimento das geociências como fundamentais, visto que o estilo de "pensamento científico tipificado pelos geocientistas são mais aplicáveis às incertezas e complexidade da sociedade moderna e, desta forma, refletem melhor as complexidades que enfrentamos como seres históricos".

Acredita-se, portanto, na eficiência de uma abordagem dos temas referentes às geociências através de um projeto que unifique o conhecimento produzido dentro da universidade à vivência de sala de aula, estabelecendo a parceria universidade-educador-aluno concretizada de forma cíclica, onde cada etapa contribua e receba da outra no processo de construção do conhecimento, como enfatizam Schiel e Freitas (2002):

(...) uma interação prolongada Universidade/Escola, através de ações que levem à construção conjunta de uma sistemática de atividades de atualização e reflexão sobre a prática pedagógica, (...) a valorização profissional dos docentes, orientando-os para mudanças de postura em sua práxis, que incorporem as novas tecnologias. (...) A transformação do conhecimento acadêmico em conteúdo de ensino para as escolas dos ciclos iniciais e os subsídios para pesquisa sobre o fazer e o saber escolar.

Tal metodologia possibilita a construção do conhecimento de forma dialógica, por meio da experimentação e da interatividade, e ainda dedica maior espaço para reflexões referentes à mudança de atitudes no sentido da preservação e sobre a tomada de consciência das consequências relacionadas à forma como interagimos com o meio natural. 
É dentro dessa perspectiva que esse projeto pretende verificar e analisar a contribuição da utilização do ensino de geociências como estratégia na disseminação de práticas de educação ambiental, em vista do enorme potencial de sensibilização ambiental fornecido pelo conhecimento das ciências da Terra.

\section{Objetivos}

\section{Objetivo Geral}

Aplicar os conhecimentos das geociências no desenvolvimento de práticas de educação ambiental e utilizá-los como estratégia de convencimento da necessidade de se desenvolver uma postura sustentável junto ao meio ambiente.

\section{Objetivos específicos}

- Trabalhar temas das geociências presentes na proposta curricular de escolas da rede municipal e estadual de ensino, relacionando-os com questões de sustentabilidade.

- Aplicar oficinas de Geociências para alunos e professores em cerca de oito escolas da rede pública da cidade de São Carlos, estado de São Paulo;

- Desenvolver o pensamento ambiental a partir da difusão de informações sobre as temáticas das geociências e suas relações com a dinâmica das atividades antrópicas.

- Desenvolver uma metodologia para a criação das oficinas mantendo-se o foco na interligação entre os conhecimentos das geociências e a educação ambiental.

\section{Metodologia}

O modelo do projeto segue uma linha prático-teórica, através da aplicação de oficinas sobre a temática da geologia ambiental, trazendo o conhecimento para o mais próximo possível do cotidiano dos alunos.

Os temas sobre os quais se baseiam as oficinas foram separados em seis áreas de conhecimento, sendo que neste trabalho apresenta-se uma definição de quais seriam esses temas, porém apenas dois deles ("Rochas e Minerais" e "Solos") já tiveram suas oficinas planejadas e aplicadas, sendo estes os resultados discutidos no presente trabalho. Inclui-se também nos resultados a definição de temas das outras quatro oficinas que ainda não foram aplicadas, considerando-se que a definição desses tópicos foi baseada na articulação de conteúdo proposta e a partir do currículo das disciplinas, entre outros parâmetros detalhados nos resultados. 
Foram definidas as duas temáticas que seriam aplicadas inicialmente, desenvolvendo-se os materiais de apoio das oficinas pertinentes a cada área, sendo que estas tiveram seu conteúdo teórico de tal maneira estruturado que possibilitou sua realização em duas linhas pedagógicas: uma em que elas eram aplicadas de maneira independente, e outra em que há uma construção contínua do conhecimento através da aplicação sucessiva das oficinas com interligação entre seus conteúdos. Com isso, possibilita-se o desenvolvimento da educação ambiental embasada em conceitos de geociências de forma contínua em determinadas instituições, estabelecendo parcerias com estes locais.

As oficinas foram organizadas conforme o conteúdo programático e a faixa etária do público alvo, que em geral variou de 10 a 11 anos, de modo que as informações sejam apresentadas para fácil assimilação. Cada oficina foi programada para em média 32 participantes, devido à disponibilidade de apenas quatro monitores por oficina para orientar os alunos, com grupos de até seis membros, possibilitando que haja maior atenção dos alunos para os monitores. Esta divisão faz-se necessária também devido à limitação do material prático, para que todos os participantes possam observar e interagir na etapa de experimentação.

A escolha dos conteúdos a serem abordados em cada oficina foi feita de maneira abrangente, selecionando-se os temas "Minerais e Rochas" e "Solos" para o início do trabalho, permitindo adaptações conforme o conhecimento dos alunos, como um maior aprofundamento em determinados conceitos ou reiterações das informações de assimilação mais complexa. Os conteúdos foram apresentados de forma expositiva, mas sempre instigando o pensamento dos alunos e convidando-os a contribuir na construção da informação. Seguindo esta premissa, a conceituação foi feita questionando os alunos sobre os temas, e não apresentando diretamente as definições, utilizando-se de muitos recursos visuais e práticos para prender a atenção dos participantes.

Considerando os temas abordados pelas oficinas, buscou-se a escolha de conceitos-chave em cada oficina e de relações entre o conteúdo teórico apresentado com o cotidiano dos alunos, para desenvolver com isso os materiais práticos e de experimentação das oficinas. A criação do material de apoio baseou-se no suporte fornecido pelo Laboratório de Geociências da Universidade Federal de São Carlos, que permitiu o acesso e utilização do seu acervo, como a coleção de rochas, minerais e solos, entre outros recursos utilizados pelo grupo de atuação para construir as oficinas.

As questões ambientais relativas a cada oficina são exploradas ao longo de sua realização, aproveitando a explicação de determinados temas e conceitos em que seja possível abordar a ação antrópica e suas relações com o ambiente, destacando a dependência existente entre estes fatores, possibilitando o processo de sensibilização ambiental e valorização dos serviços ecossistêmicos. 
Um aspecto ainda importante do projeto é avaliar o impacto das oficinas sobre os alunos, o nível de sensibilização ambiental e absorção dos conceitos. A avaliação inclui um diagnóstico dos conhecimentos dos participantes sobre o tema desenvolvido, o que permite mensurar as influências da atividade. As formas de realizar tal etapa também são adaptadas à faixa etária e capacidade cognitiva dos participantes. Sendo assim, com base nos resultados obtidos é possível reformular e adaptar as abordagens das oficinas, buscando fortalecê-las em seus aspectos considerados mais falhos.

Outra linha de atuação foi feita de forma paralela junto aos professores, onde para esse público foram disponibilizados minicursos com duração de quatro horas, aplicados no próprio espaço da escola ou no laboratório de Geociências da Universidade sede do projeto, a critério da escola. Os temas trabalhados seriam os mesmos das oficinas mudando apenas a abordagem, neste caso, o objetivo foi disponibilizar aos professores acesso a tecnologias e parte do material utilizado nas oficinas bem como uma atualização conceitual sobre os conteúdos abordados, de forma que sejam capazes de dar continuidade ao trabalho.

É com base nessa ideia de incentivo à reprodução e continuidade que se procurou utilizar na confecção das oficinas materiais alternativos e de fácil acesso. Foram disponibilizados ainda, aos educadores, os roteiros de cada oficina, onde se descreve com detalhes cada etapa da mesma, possibilitando sua reprodução a critério do professor.

Ainda nessa linha de apoio ao educador, abre-se espaço para o estabelecimento de uma parceria mais abrangente com a escola, com o apoio a realização de projetos criados. Neste caso específico este projeto pode tomar proporções que extrapolam as previsões e objetivos aqui estabelecidos, uma vez que torna-se parceiro das instituições, o que possibilita o desenvolvimento de projetos dentro do ambiente escolar pensados de maneira conjunta desde 0 seu início, desenvolvimento e aplicação, utilizando temas referentes às geociências.

\section{Resultados e Discussão}

Como resultado preliminar à execução das oficinas considera-se a metodologia de articulação de conteúdo produzida, com o objetivo de facilitar a construção das atividades do projeto onde foram desenvolvidos tópicos que seriam prioritários conforme os seguintes princípios: importância para o tema central (que consiste no potencial de utilização do mesmo como estratégia de educação ambiental), relação com a questão ambiental, potencial de assimilação pelos participantes, e presença na grade curricular nas redes municipais e estaduais de ensino.

Levou-se em conta ainda a estruturação da oficina, pois alguns temas necessitam de conhecimento prévio de conceitos específicos ou até mesmo de 
outras áreas selecionadas para serem abordados de forma mais produtiva possível. Sendo assim, os temas escolhidos e seus respectivos tópicos foram:

Dinâmica interna da Terra e Vulcanismo: introduzir conceitos relacionados à formação da Terra e às características do magma; processo de resfriamento e formação da crosta; tectônica de placas; vulcanismo e energia geotérmica.

Minerais e Rochas: discussão do conceito de rochas e minerais; a aplicação dos diferentes tipos de minerais nas atividades humanas; a extração de rochas e minerais e os impactos ambientais associados; ações e medidas para a conservação do ambiente.

Solos: a formação do solo e suas características; os diferentes usos da terra e seus impactos sobre o solo; a influência da cobertura vegetal na proteção do solo; os processos de infiltração e escoamento superficial relacionados à erosão.

Águas subterrâneas: conceito de aquífero e água subterrânea; processo de infiltração e recarga de aquíferos; extração e uso do recurso hídrico subterrâneo; contaminação e técnicas de descontaminação.

Orientação espacial: orientação espacial através do reconhecimento de marcos na paisagem; sistemas de localização geográfica; orientação através de coordenadas geográficas; a tecnologia na orientação espacial (GPS).

Nascentes: importância dos sistemas subterrâneos no ciclo hidrológico; a contribuição das nascentes para os corpos hídricos superficiais; o papel da vegetação na proteção de nascentes; susceptibilidade das nascentes frente à ação antrópica.

Tal divisão e escolha dos conteúdos seguiu os princípios acima mencionados e foi utilizada como orientação para a elaboração das oficinas, considerando a melhor adequação temporal à grade curricular das escolas. Segue abaixo uma descrição mais detalhada da metodologia geral desenvolvida para a criação das oficinas seguida de sua aplicação nas oficinas de minerais e rochas e solos. Os resultados das demais temáticas definidas nesta primeira fase, não serão tratados neste trabalho.

\section{Passos para o desenvolvimento das oficinas}

A partir da seleção dos tópicos descritos acima escolheu-se se um principal, o qual será o foco da oficina em estruturação. A partir deste foco definiram-se os conhecimentos básicos necessários previamente para um bom entendimento da temática central que deveriam ser abordados durante a oficina. Opcionalmente, conforme fosse verificada a necessidade de conceituação de um determinado conhecimento e, ao longo da elaboração da oficina este se tornasse extenso demais para ser utilizado apenas na caracterização preliminar, tal tópico poderia vir a ser trabalhado isoladamente 
em uma única oficina. Esta oficina, desta forma, tornar-se-ia um pré-requisito para a aplicação do tema central definido anteriormente para a outra, o que condiz com os pressupostos de que o processo de construção é contínuo e a articulação entre conteúdos deve ser realizada.

Após este processo, foi realizada então uma busca dos conteúdos adjacentes ao tema central da oficina que deveriam ser trabalhados para que houvesse a exploração de questões ambientais relacionadas e a consolidação do conhecimento, o que levou à seleção de outros tópicos para a oficina, dentre os descritos anteriormente, considerados tópicos acessórios.

Por fim, através da metodologia de articulação de conteúdo, as oficinas foram estruturadas sobre um tema central que apresenta um tópico principal, tópicos preliminares e tópicos acessórios (Figura 1).

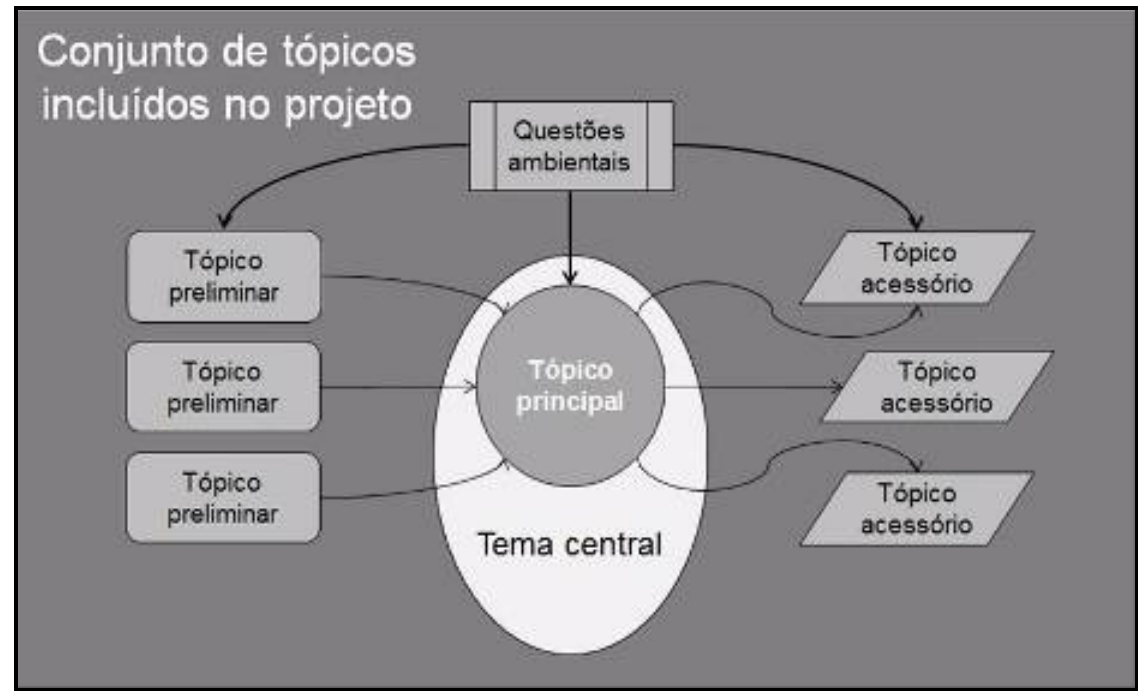

Figura 1: Fluxograma do processo de elaboração da oficina através da articulação de conteúdo. Fonte: Próprio autor (2013)

\section{Oficina sobre Minerais e Rochas}

As primeiras oficinas construídas com esta técnica foram as de Minerais e Rochas (Tabela 1), a qual teve como objetivos: caracterizar os tipos de rochas e minerais e relacioná-los com seus respectivos usos, bem como as consequências dos processos extrativistas para o meio ambiente natural.

Tais oficinas foram aplicadas na Escola Municipal de Ensino Básico Maria Ermantina Carvalho Tarpani (São Carlos, SP), em duas turmas de quinto ano, faixa etária entre 10 e 11 anos de idade, sendo a oficina da turma 1 realizada no mês de abril de 2012, e a oficina da turma 2 no mês de maio de 2012, seguindo a proposta de realizar oficinas mensalmente. Em tal atividade pretendia-se que os estudantes relacionassem Minerais e Rochas, disponíveis para a visualização, com elementos do espaço de suas casas, além de instigar sobre sua formação, métodos de extração e escassez. 


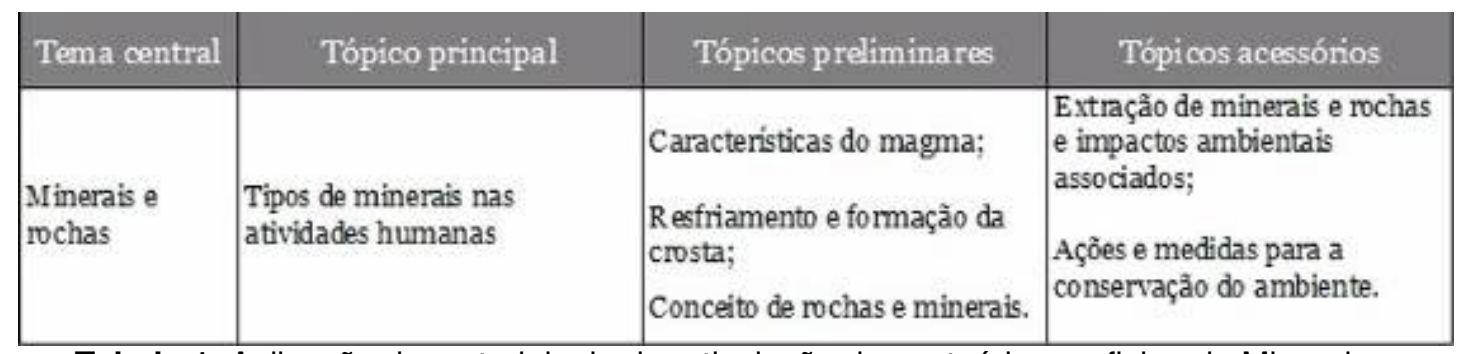

Tabela 1: Aplicação da metodologia de articulação de conteúdo na oficina de Minerais e Rochas. Fonte: Próprio autor (2013)

A oficina baseou-se na aproximação da temática de rochas e minerais para o cotidiano dos alunos, pois esta estratégia permite uma aplicação mais próxima e direta dos conceitos apresentados e potencializa o processo de aprendizagem. Desta forma, foram utilizados exemplos do emprego de minerais em objetos presentes em determinados espaços de uma casa. Anteriormente à prática foram feitos os questionamentos, através dos quais o conteúdo teórico foi explanado. Entre as perguntas feitas estão: "O que é um mineral? ", "De que tipo de material é feita sua casa? ", "Onde estão os minerais em nosso dia-a-dia?", "Nós precisamos dos minerais? ", "Alguém pode citar um mineral conhecido?", "Como os minerais se transformam nos produtos?" e "Como retiramos os minerais da natureza?". Quanto à parte teórica foi possível inferir que os questionamentos propostos foram satisfatórios em cumprir o objetivo de gerar participação constante e como mecanismo de assimilação de informação. Tal observação foi constatada uma vez que todas as perguntas foram respondidas pelos alunos durante a apresentação, em alguns momentos corretas conceitualmente e em outros sendo necessária uma explanação teórica, de modo que as informações transmitidas foram relembradas no questionário realizado ao término da oficina, como será apresentado nos resultados discutidos a seguir. Também é necessário adicionar que houve a percepção pela equipe do projeto de que as perguntas foram um pouco repetitivas, o que levou a reformulações a partir da segunda oficina aplicada com o mesmo tema.

Durante a parte prática os alunos foram divididos em quatro grupos, cada grupo responsável por um cômodo da casa, que continha de seis a oito objetos relacionáveis a algum mineral (Tabela 2) com base na exploração de suas características. Com a ajuda do monitor os alunos associaram figuras de objetos aos minerais, fazendo um trabalho de colagem dessas figuras sobre a casa confeccionada pela equipe do projeto e escrevendo o nome do mineral com qual o objeto era produzido (Figura 2). 


\begin{tabular}{|c|c|c|c|c|c|}
\hline \multicolumn{6}{|c|}{ Oficina de minerais e rochas } \\
\hline Cómodo & Objeto & Mineral & Cámodo & Objeto & Mineral \\
\hline \multirow{8}{*}{ Cozinha } & Prato & feldspato & \multirow{8}{*}{ Sala } & Sofâ & cromita \\
\hline & Panela-de-barro & argila & & Televisăo & wolframita \\
\hline & Torradeira & hernatita & & Controle remoto & cobre \\
\hline & Liquidificador & cromita & & Telefone & grafita \\
\hline & Janela & quartzo & & Mesa & hematita \\
\hline & Geladeira & galena & & Vaso-de-flor & caulim \\
\hline & Fogão & cobre & & Tapete & esfarelita \\
\hline & Pia & calcário & & Chapeleiro & bauxita \\
\hline \multirow{7}{*}{ Quarto } & Mesa & bauxita & \multirow{7}{*}{ Banheiro } & Espelho & prata \\
\hline & Cadeira & cromita & & Toatha & esfarelita \\
\hline & Cama & hematita & & Pia & caulim \\
\hline & Cehilar & cobre & & Banheira & feldspato \\
\hline & Luminäria & quartzo & & Vaso sanitario & argilita \\
\hline & Computador & wolframita & & Pasta de dentes & fluorita \\
\hline & Lápis de cor & grafita & & Jancla & quartzo \\
\hline
\end{tabular}

Tabela 2: Relação dos objetos utilizados na oficina de Minerais e Rochas e dos minerais a eles associados. Fonte: Próprio autor (2013)

Por fim, a questão ambiental central que foi levantada para esta oficina estava relacionada com os impactos que a atividade de mineração pode causar ao ambiente e à população, como degradação dos corpos hídricos, alteração da geomorfologia da paisagem, perda de biodiversidade, poluição sonora, remoção de populações instaladas, condições de insalubridade ao trabalhador e riscos à saúde dos moradores nas áreas adjacentes. Em contraponto foi exposta a demanda constante que a sociedade apresenta para com a extração de minerais, deixando claro sua característica de recursos não renováveis. Com isso, o questionamento proposto aos alunos foi como continuar explorando os recursos minerais necessários, mas evitando a degradação do ambiente com esta atividade e sua superexploração, estimulando-os a apresentar alternativas adotáveis ao seu cotidiano.

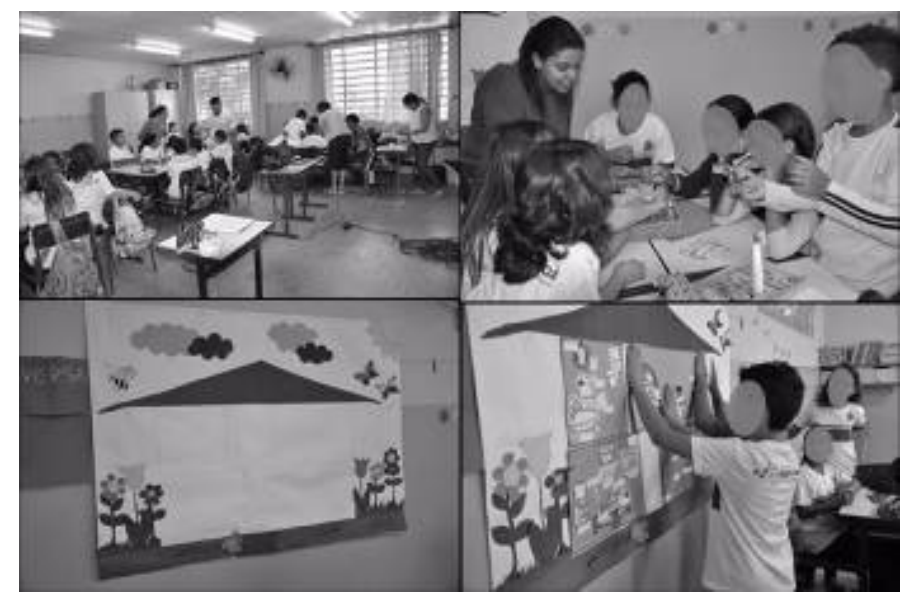

Figura 2: Confecção e montagem da casa durante a atividade prática da oficina de Minerais e Rochas. Fonte: Próprio autor (2013) 
Tais respostas e verificações quanto à absorção do conteúdo foram analisadas por meio do questionário proposto (Anexo 1). Este mecanismo de avaliação foi elaborado em nove questões discursivas (Anexo 1), através das quais é possível avaliar o conhecimento preliminar dos alunos sobre minerais, a sua importância, o emprego dos minerais no cotidiano, os impactos causados pela atividade de mineração, e por fim sugestões e atitudes possíveis frente à problemática. O questionário foi aplicado ao fim da oficina, pois se entende que sem a explanação do tema ao longo da oficina nem todos alunos compreenderiam os conceitos envolvidos no questionário.

Dentre as respostas em relação ao questionário foi possível verificar uma maior facilidade de associação dos alunos com o mineral quartzo e objetos relacionados do que qualquer outro mineral, corroborando com a hipótese de que a identificação é facilitada pelo contato direto, considerando que o quartzo é visualmente característico e assimilável. Adiciona-se a essa hipótese outros minerais, que apesar de não serem a maioria, também foram mais facilmente identificáveis, como a argila, que é característica pela sua textura, e a magnetita, devido a sua propriedade de magnetismo.

De forma diagnóstica, perguntou-se com o questionário se o aluno já conhecia algum tipo de mineral, e como apresentado no gráfico abaixo (Figura 3), em ambas as turmas a porcentagem que afirmou conhecer um mineral variou de $47 \%$ a $54 \%$, uma diferença que não é considerada expressiva.

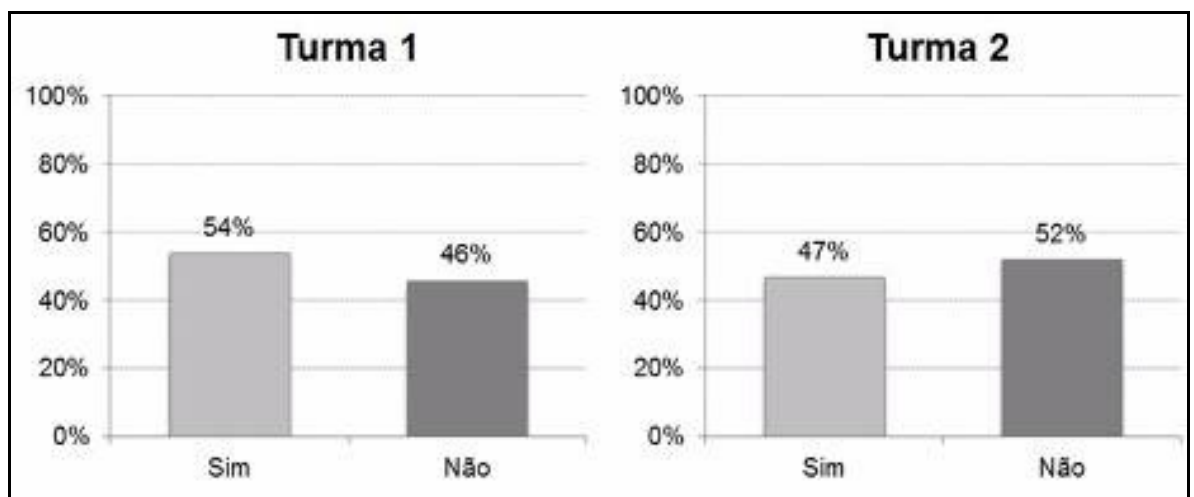

Figura 3: Análise das respostas dos questionários referentes ao conhecimento prévio (sim ou não) dos alunos sobre minerais (questão 1 - Você já conhecia algum mineral?).

Fonte: Próprio autor (2013)

Os resultados indicam se as crianças conhecem ou não os minerais, e não necessariamente qualificam seu conhecimento anterior sobre o tema. Apesar disso, é possível considerar a quantificação dos dados como percepção, ressaltando o fato de que esta pode ou não já ter sido adquirida anteriormente a discussão sobre o tema. O que não exclui a importância de se ter tal percentual como positivo para essa questão. Além disso, pode existir certa ambiguidade na questão, pois muitos alunos citaram objetos ao invés dos minerais que os compõem, como "latinhas" ao invés de bauxita e "vidro" ao invés de quartzo. Entende-se então que por volta de $50 \%$ afirmam já ter visto 
algum mineral, enquanto outros $50 \%$ atingiram o mesmo objetivo ao final da oficina, pois todos citaram ao menos um mineral ao longo do questionário. A questão da ambiguidade poderia ser solucionada propondo o seguinte questionamento: "Você já sabia o que é um mineral e que eles estão presentes em vários objetos? ", considerando que o objetivo de tal indagação é detectar um conhecimento prévio dos alunos sobre o tema.

O segundo gráfico (Figura 4) aponta o aumento da percepção quanto à importância dos minerais através da análise da questão 2: "Pelo que você pode perceber, os minerais são importantes para a gente? "Este aumento se mostrou muito significativo em ambas as turmas, atingindo quase todos os alunos, que em alguns casos além de afirmarem saber a importância dos minerais disseram que estes "são necessários para fazer vários objetos", até mesmo citando alguns minerais como a bauxita, "(...) pois sem ela nós não vivemos", dando ênfase à sua fundamentalidade para produzir alguns bens e serviços, como na citação "senão nós não teríamos o ferro". Apesar do erro teórico da última citação (o mineral correto é a hematita), é reconhecível que o aluno foi capaz de associar um mineral a um produto, que é a proposta da oficina. Mas como a assimilação dos conceitos também é um dos objetivos das práticas, faz-se necessário a criação de um mecanismo de retorno às professoras para sanar erros como este verificado nos questionários, e que será aplicado às próximas oficinas.

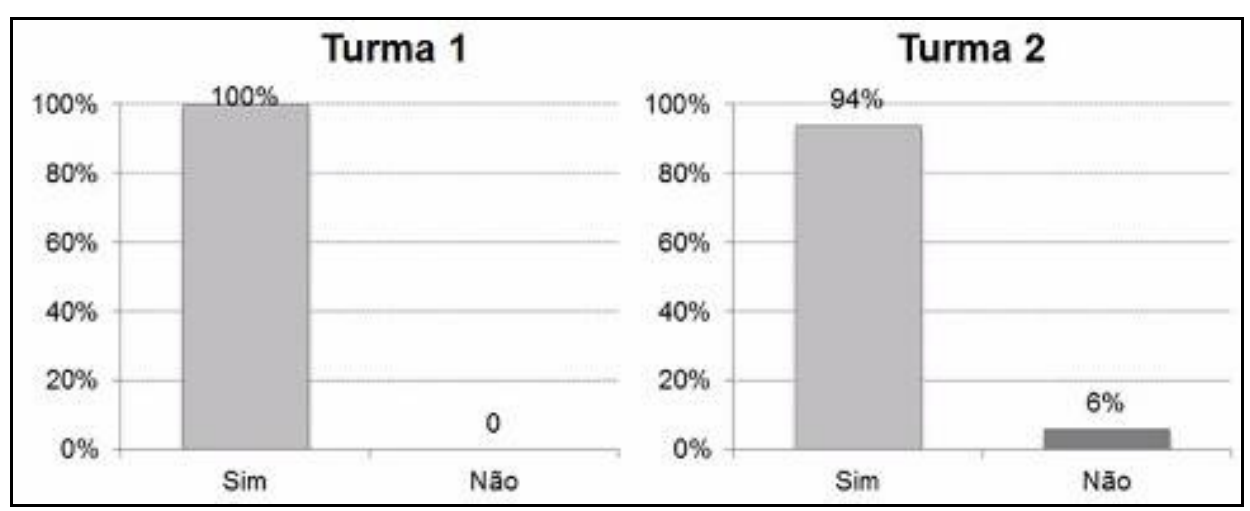

Figura 4: Análise das respostas dos questionários verificando se houve aumento (sim ou não) da percepção dos alunos quanto à importância dos minerais. Fonte: Próprio autor (2013)

Ao avaliar de modo geral a capacidade dos alunos de associar algum mineral a um objeto os resultados apresentaram uma maior disparidade entre as turmas (Figura 5). Exemplos de associações positivas incluem: "bauxita faz o alumínio do armário, né? ", "quartzo no vidro da janela e da luz", "a argila que faz os vasos", etc.

Na turma 1, 46\% dos alunos conseguiram estabelecer alguma relação, o que foi julgado um ponto a ser reforçado nas próximas oficinas. Sendo assim, buscou-se retomar constantemente na oficina seguinte as possíveis relações entre alguns minerais e objetos, dando atenção maior àquelas em que a associação pelos alunos foi considerada mais assimilável. Com isso, a 
resposta obtida pela turma 2 foi que $65 \%$ dos alunos estabeleceram algum tipo de associação, o que é um aumento em 19\%. Verifica-se uma diversidade de minerais citados considerada satisfatória (quartzo, argila, bauxita, magnetita, feldspato, cromita, hematita e grafita), mas ainda assim alguns deles não são lembrados, como o talco e fluorita, verificando-se a necessidade de maior ênfase nesses durante a prática.

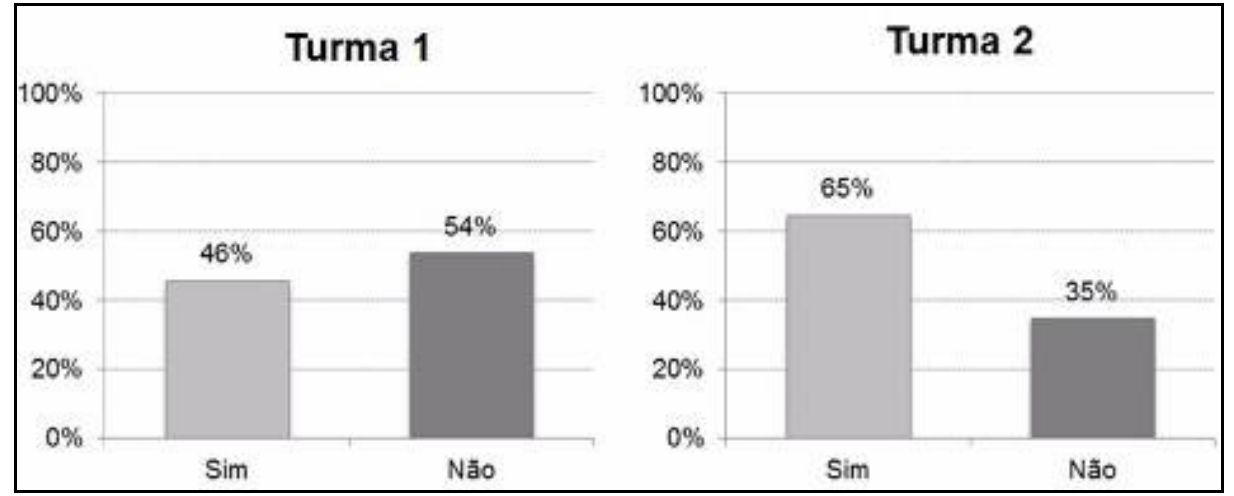

Figura 5: Análise das respostas dos questionários verificando se os alunos foram capazes (sim ou não) de relacionar minerais a alguns objetos (questão 3 - Você conhece ou utiliza algum objeto feito de minerais?; questão 4 - Dos minerais que você conheceu na atividade tem algum que você conseguiu associar a objetos da sua casa?; questão 5 - E na sua escola tem objetos

feitos a partir de algum mineral que você conheceu?). Fonte: Próprio autor (2013)

Em seguida, os alunos eram questionados quanto à localização dos minerais na natureza, à sua forma de obtenção (questão 6: "Onde ficam os minerais na natureza? Você considera que é fácil sua extração? " Respostas obtidas: "embaixo da terra" e "embaixo das árvores") e se sua retirada oferece riscos ao ambiente (questão 7: "Pelo que você percebeu, a retirada de minerais da natureza prejudica o meio ambiente?" Respostas obtidas: "sim, pois para arrancá-los temos que cortar as árvores" ou "sim, a água e as árvores") (Figura 6). Ambas as turmas mostraram resultados similares, mas assim como na análise anterior houve um aumento da turma 1 (77\%) para a turma $2(88 \%)$ daqueles que souberam responder satisfatoriamente às questões. Mas esta é uma diferença não tão expressiva frente à maior subjetividade das respostas fornecidas pelos alunos para as questões pertinentes a esta análise, o que não demonstra que tal diferença se deu em função de alguma modificação na estrutura da oficina quanto a estes tópicos, pois esta alteração não foi considerada necessária em vista do resultado obtido pela turma 1 que já havia sido julgado satisfatório. 


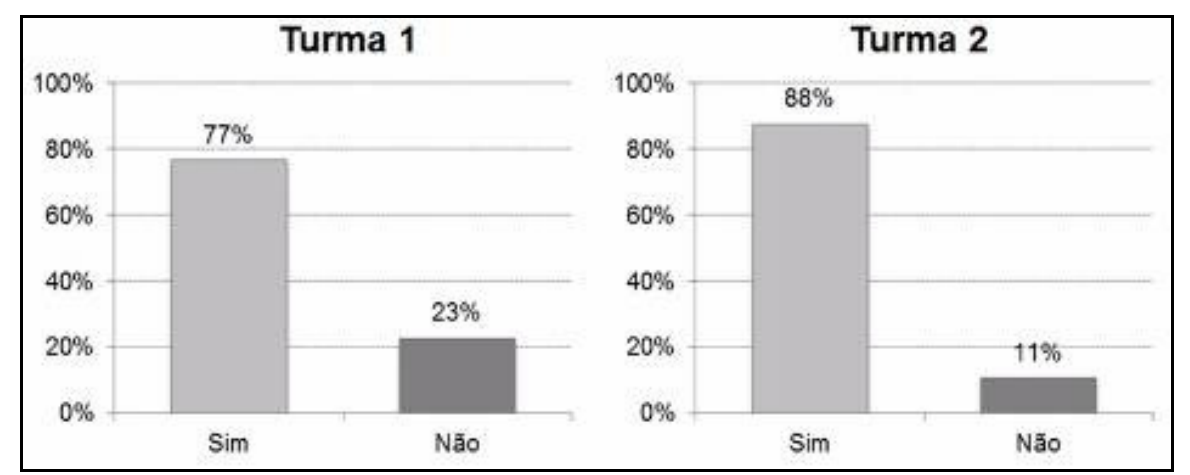

Figura 6: Análise das respostas dos questionários quanto à compreensão (sim ou não) dos alunos sobre o processo de extração de minerais e dos problemas ambientais a ele relacionados. Fonte: Próprio autor (2013)

Por fim, as perguntas finais do questionário estimulavam os alunos a apresentarem soluções para a problemática da mineração, primeiramente de um modo mais geral (Figura 7) e em seguida por meio de ações que eles pudessem adotar em seu cotidiano (Figura 8).

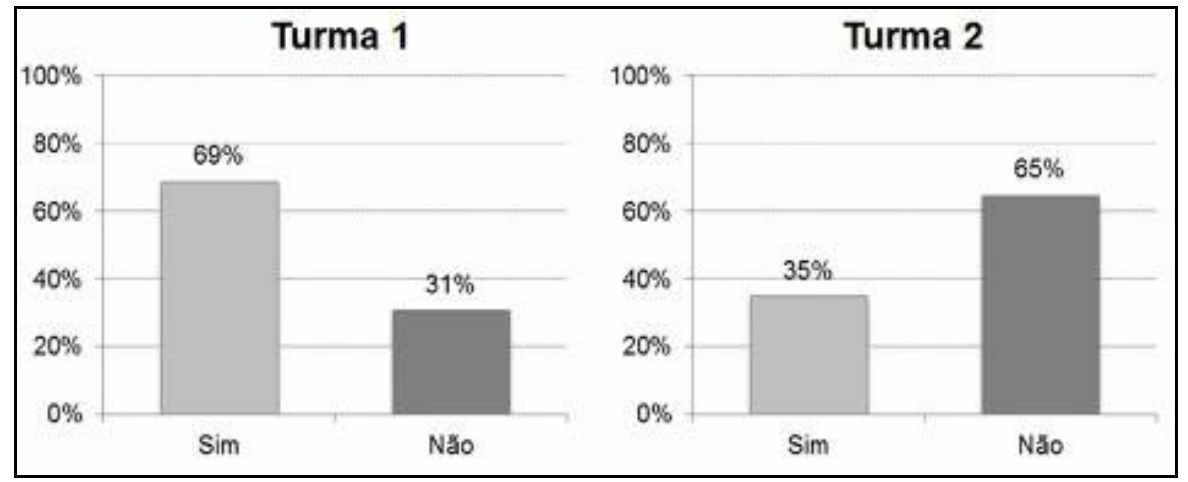

Figura 7: Análise das soluções apresentadas pelos alunos quanto à problemática geral da mineração verificando se eram pertinentes (sim ou não) ao tema (questão 8: Que tal você nos ajudar a pensar em uma forma de continuar utilizando os minerais, mas também sem destruir tanto a natureza? Resposta pertinente: "não jogar fora os materiais que sobrar").

Fonte: Próprio autor (2013)

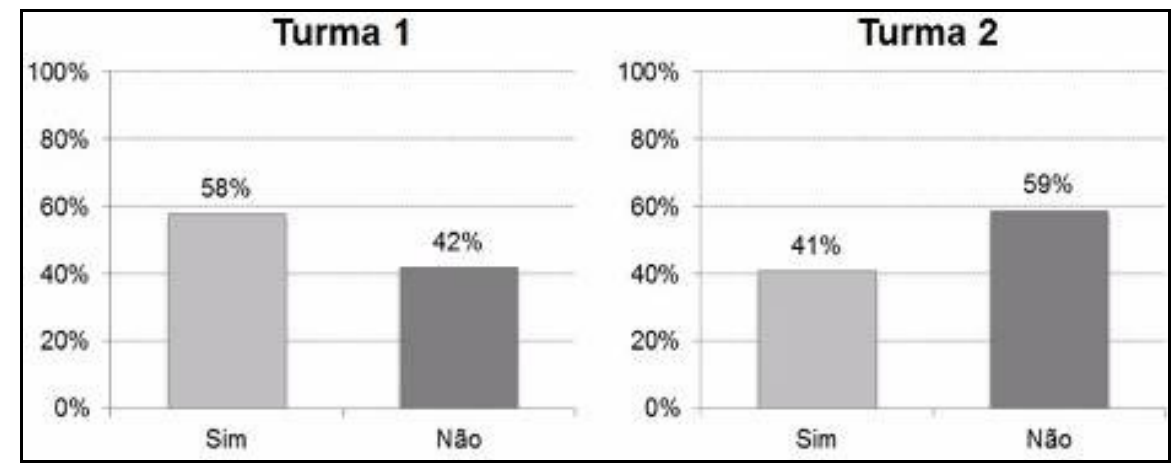

Figura 8: Análise das ações e posturas sugeridas pelos alunos adotáveis ao cotidiano frente à questão ambiental exposta verificando se eram pertinentes (sim ou não) ao tema (questão 9: "Será que a gente na nossa casa e em nossas brincadeiras pode ajudar a diminuir mesmo que um pouquinho a retirada de minerais da natureza?" Respostas pertinentes: "a latinha, usar para fazer um brinquedo" ou "reciclar os materiais”). Fonte: Próprio autor (2013)

Revbea, São Paulo, V.10, N²: 204-227, 2015. 
Ao analisar comparativamente as duas turmas ocorreu uma inversão dos resultados entre a turma 1 e a turma 2, de modo que a proporção daqueles com propostas adequadas na turma 1 foi a proporção daqueles com propostas inadequadas na turma 2. Considerou-se a resposta da turma 1 muito satisfatória, em que $69 \%$ dos alunos trouxeram soluções de modo abrangente, de fato relacionadas ao tema, e $58 \%$ apresentaram medidas passíveis de serem adotadas no cotidiano que foram discutidas durante a oficina. Mas ao se analisar os questionários da turma 2 ficou evidente que "parar de gastar água" se tornou uma resposta recorrente para solucionar a problemática, sendo que tal medida não foi discutida de maneira significativa durante a oficina por não ser a mais pertinente ao tema. A este fato atribui-se a disparidade verificada entre as duas turmas, pois apenas $35 \%$ dos alunos na turma 2 mostraram soluções abrangentes relacionadas ao tema e 41\% trouxeram medidas adotáveis ao cotidiano. Tal irregularidade nos dados relaciona-se possivelmente a citação da utilização exacerbada de água e poluição dos rios nos processos de extração de minerais, seu beneficiamento e emprego como um problema ambiental grave, o que pode ter causado maior influência na assimilação das informações do que o esperado. Além disso, este efeito é maximizado tendo em vista que a temática água é recorrente durante as aulas regulares, sendo incluída em diversas pautas da grade curricular, o que pode influenciar os alunos a um vício de apresentarem respostas direcionadas quando questionados acerca de problemas ambientais. Este fato está previsto e eleva a importância do projeto, já que existe tamanha escassez na abordagem dos tópicos em geociências dentro das escolas. É necessário um aumento da abrangência do conceito de problema ambiental, não o reduzindo apenas as questões de gasto de água e energia, mas também a outros problemas em destaque como os relacionados às geociências, que devem ser enfatizados nas oficinas e orientados aos próprios educadores.

Apesar do resultado quantitativo insatisfatório neste caso, verifica-se que foram propostas soluções bem trabalhadas, como "reciclar os materiais", "reutilizar as coisas que usamos", "não desperdiçar e espalhar a informação" e "usar a latinha de alumínio para fazer um brinquedo", evidenciando que as respostas as oficinas se desvencilham do comum, incluindo-se também argumentações nem sempre recorrentes, como a reutilização e a difusão de informações, que são de máxima importância para a formação ambiental.

De modo geral, foi possível constatar que o uso de recursos didáticos práticos chamou a atenção dos alunos, que se mostraram interessados ao tema e trouxeram em todos os momentos contribuições e relatos pessoais.

\section{Oficinas sobre solos}

Posteriormente a aplicação das duas oficinas descritas, partiu-se então para a formulação de uma oficina com outra temática, seguindo o mesmo método de articulação do conteúdo, com a escolha dos solos para a abordagem central (Tabela 3). 


\begin{tabular}{|c|c|c|l|}
\hline Tema central & \multicolumn{1}{|c|}{ Tópico principal } & Tópicos preliminares & \multicolumn{1}{|c|}{ Tópicos acessórios } \\
\hline Solos & Processos de infiltração. & Conceito de rochas e minerais. & $\begin{array}{l}\text { A formação do solo e suas } \\
\text { caracteristicas; } \\
\text { Diferentes usos da terra e seus } \\
\text { impactos sobre o solo; } \\
\text { Influência da cobertura vegetal } \\
\text { na proteção do solo; } \\
\text { Importância dos sistemas } \\
\text { subterrâneos no ciclo } \\
\text { hidrológico. }\end{array}$ \\
\hline
\end{tabular}

Tabela 3: Aplicação da metodologia de articulação de conteúdo na oficina de Solos.

Fonte: Próprio autor (2013)

Sua aplicação foi proposta na Escola Municipal de Ensino Básico Antônio Stella Moruzzi, para duas salas do quinto ano do ensino fundamental, faixa etária entre 10 e 11 anos de idade, com uma duração mais extensa, cerca de 4 a 5 horas.

O trabalho teve foco na importância do processo de infiltração e nas consequências dos diversos usos. Com isso, a abordagem foi feita com o objetivo de possibilitar a diferenciação e identificação pelos estudantes de alguns tipos de solos principais e demonstrar a influência dos usos no processo de infiltração, de modo a levar à análise e reflexão sobre as consequências de cada uso, bem como a necessidade e importância da adequação da escolha do solo conforme o tipo de ocupação.

A oficina foi dividida em quatro momentos, o primeiro foi de diagnóstico, com duração aproximada de trinta minutos, onde se procurou verificar conhecimentos prévios sobre o tema. Para isso, foi entregue uma folha de A4 em branco para cada aluno e pedido que desenhassem o que imaginavam sobre solos. Resumidamente o solo foi desenhado contendo fragmentos de diferentes tamanhos, contendo água, espaços vazios e seres vivos, porém nem todos atributos estavam em todos os desenhos ou apareceram na mesma abundância, como descrito com detalhe na Figura 10.

O segundo momento, com duração aproximada de 2 horas, foi dedicado à explanação de conceitos teóricos. Para isso, o desenvolvimento do tema foi estruturado abordando principalmente: conceitos de solos, processos de formação do solo, perfil do solo, classificação física do solo, infiltração de água no solo, sua relação com o ciclo hidrológico e com os diversos usos e ainda exemplos de mau uso do solo e suas consequências.

Nesta etapa, além do recurso audiovisual utilizaram-se demonstrações feitas em garrafa pet, uma com um exemplo de perfil do solo, e mais três, onde utilizando-se o mesmo tipo de solo, montou-se simulações de situações de solo impermeabilizado, solo com a cobertura vegetal e outra de solo compactado. Utilizou-se ainda uma maquete na qual se procurou demonstrar vários exemplos de uso inadequado do solo bem como suas consequências. Estavam presentes na maquete situações como escorregamentos, ausência de APP (Área de Preservação Permanente), contaminação e desmatamento, 
compilando tudo de forma harmônica em uma paisagem que incluiu tanto o ambiente urbanizado quanto suas adjacências rurais.

O terceiro momento com duração aproximada de 1 hora e 30 minutos, seguindo a metodologia definida, foi dedicado às experimentações, as quais foram sempre feitas em grupos, com o acompanhamento dos monitores. Para esta etapa foram montados em garrafas pets, funis com três tipos de solo: um predominantemente argiloso, um arenoso e um intermediário areno-argiloso, onde os estudantes realizaram o experimento seguindo um roteiro (Anexo 2), onde água era inserida nos diferentes funis ao mesmo tempo, sendo que a partir disso os alunos deveriam concluir, entre outros itens, em qual tipo de solo ocorreu a infiltração da água mais rapidamente e por que, com base nos conceitos teóricos apresentados no momento anterior. Foi pedido também que estabelecessem a relação entre o processo de infiltração e o ciclo hidrológico, bem como a reflexão sobre as consequências dos tipos de uso do solo pelo homem neste processo.

Ao final, com duração aproximada de 30 minutos, foram entregues novamente folhas de A4 em branco aos estudantes e pedido que desenhassem novamente respostas a mesma pergunta feita no início da oficina, de forma que fosse possível comparar e verificar sua assimilação tanto dos conceitos quanto da aplicação desse conhecimento em atitudes que contribuam com a preservação e uso racional do solo. Com isso foi pedido ainda que sugerissem formas de uso que favorecessem o processo de infiltração de água no solo (Figura 9).

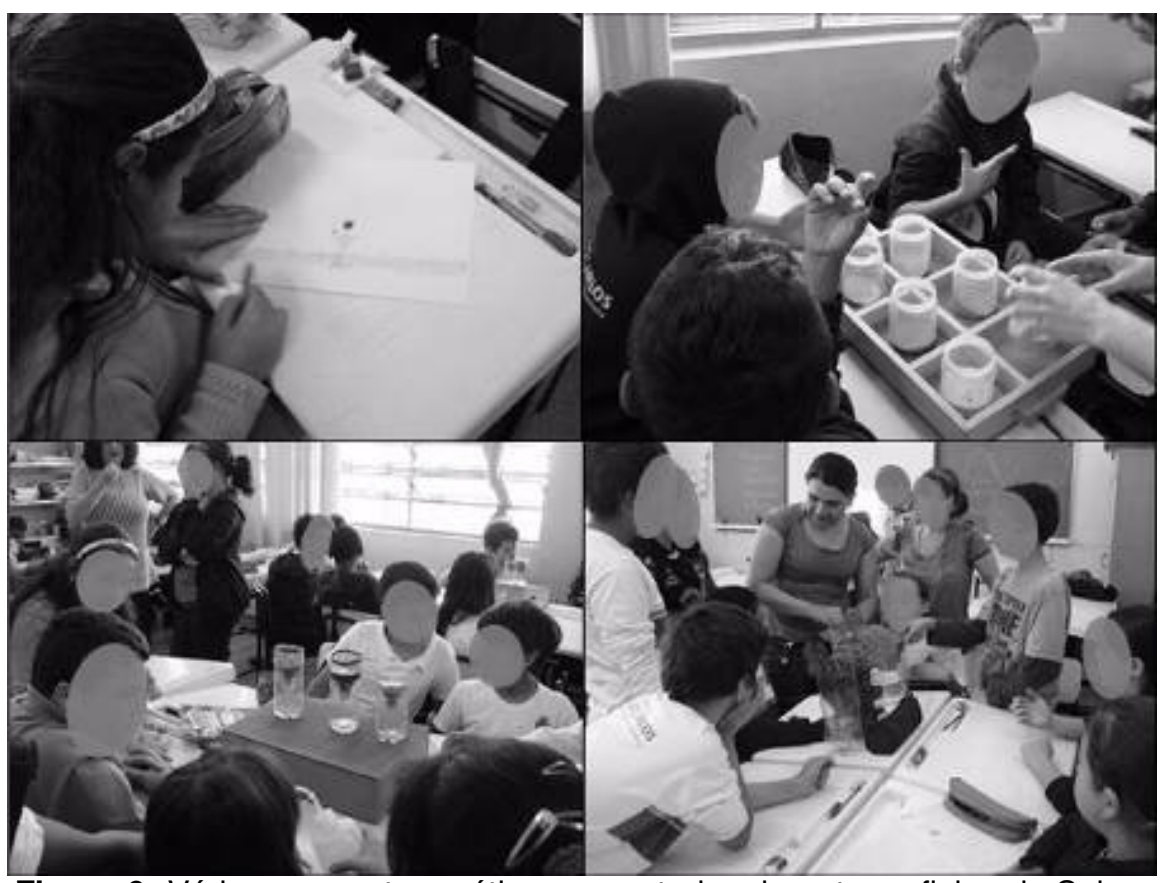

Figura 9: Vários momentos práticos executados durante a oficina de Solos.

Fonte: Próprio autor (2013) 
O resultado da comparação entre os desenhos feitos nos dois momentos foi compilado em três gráficos, classificados conforme os temas predominantes e a necessidade de verificação do alcance dos objetivos de aprendizagem almejados. Resultando nos temas: Caracterização do solo, Uso e ocupação e Relação com o ciclo hidrológico.

Quanto à aprendizagem sobre as características do solo (Figura 10), percebe-se pela comparação entre os componentes presentes, dos desenhos feitos inicialmente e ao final da oficina, que os estudantes já tinham certo conhecimento sobre esse tema, ao menos no que diz respeito a formação do solo ser a partir da fragmentação da rocha e a presença de biota no mesmo. Em relação aos outros itens trabalhados, com exceção do ar, houve indicativo de aumento do conhecimento em todos. Tal afirmação é evidenciada pelo aumento da presença de elementos de Matéria Orgânica, Água Subterrânea e Superficial e os Horizontes do Solo retratados nos desenhos finais em relação aos desenhos iniciais, sendo que a diferença entre o número de vezes que os Horizontes do Solo foram retratados entre o desenho diagnóstico e o desenho realizado no último momento foi a mais substancial, de $20 \%$ para $38 \%$. Isso ocorreu possivelmente por esse tema, Horizontes do Solo, ser de difícil demonstração em aulas tradicionais, o que explicaria a menor referência nos desenhos iniciais.

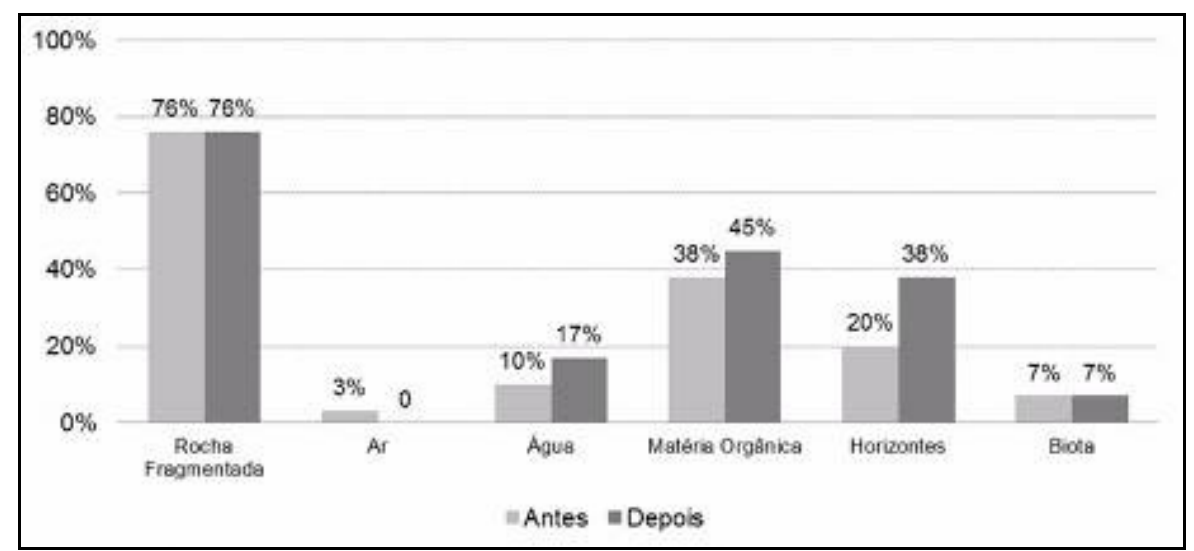

Figura 10: Análise comparativa entre os desenhos feitos pelos alunos antes e depois da oficina verificando aspectos relacionados às características do solo. Fonte: Próprio autor (2013)

Demonstrou-se, portanto que essa dificuldade foi amenizada pela representação dos perfis em pets, na parte teórica da oficina. Pode-se inferir também que a representação dos horizontes nos desenhos, anteriormente a realização da oficina, foi bem simplificada. Foi feita a representação de apenas duas camadas sem considerar outros itens, como a camada orgânica e a cobertura vegetal, itens já inclusos no desenho após a oficina (Figura 11). 


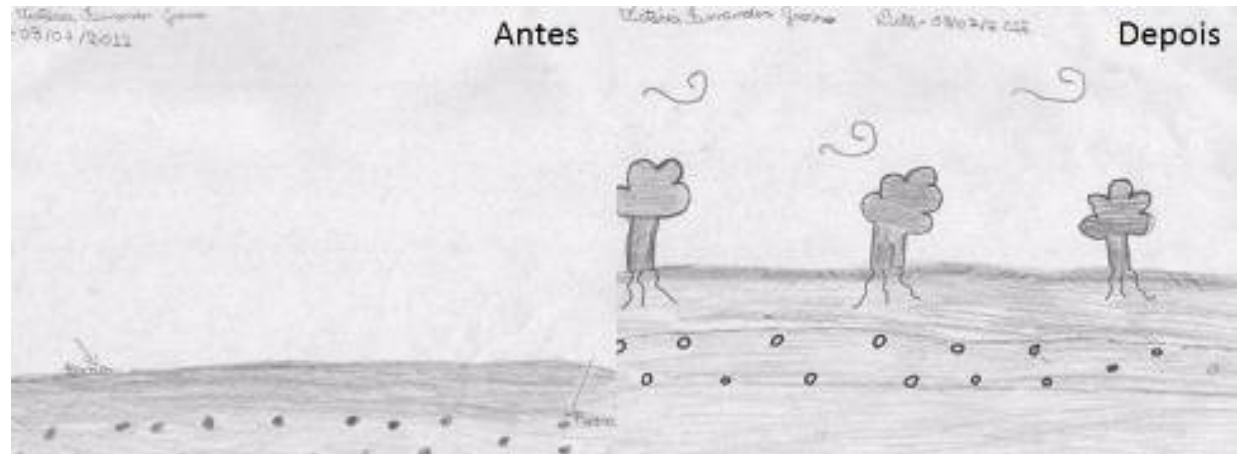

Figura 11: Par de desenhos do mesmo aluno elaborados anteriormente à oficina (tomado como diagnóstico) e após a discussão dos conceitos. Fonte: Próprio autor (2013)

Em relação à percepção sobre processos referentes ao uso e ocupação (Figura 12), a comparação entre os dois desenhos indica que, mesmo em diferentes intensidades, os objetivos quanto a estes aspectos foram alcançados plenamente, uma vez que os primeiros desenhos, apesar da inclusão da vegetação nativa, apresentaram predominantemente solos simplificados e antropizados, o que é indicado pela presença de gramíneas, relevo plano e alguma forma de cultivo. Já nos desenhos finais, havia menos gramíneas e mais vegetação arbórea, menor referência ao cultivo e ainda uma apresentação de relevo mais próxima da realidade, com a representação de padrões de declividade. Atribui-se essas mudanças às explanações teóricas, somadas ao uso de maquetes para demonstrar a importância deste aspecto na preservação do solo, feitas durante a oficina.

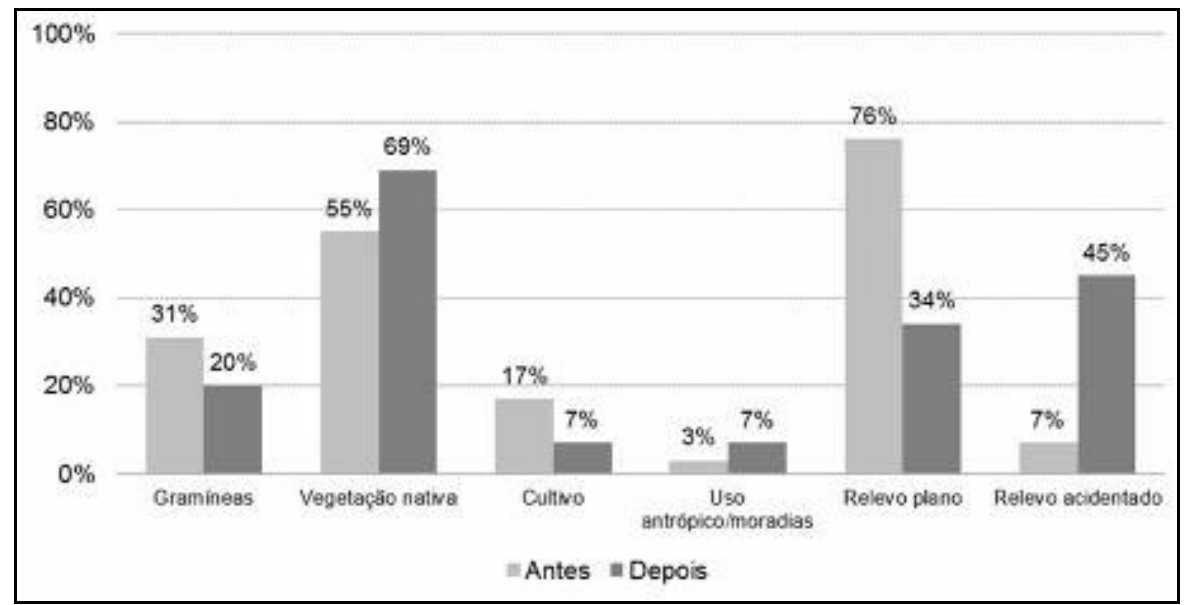

Figura 12: Análise comparativa entre os desenhos feitos pelos alunos antes e depois da oficina, verificando aspectos relacionados ao uso e ocupação do solo.

Fonte: Próprio autor (2013)

Essa representação do relevo nos desenhos finais também é consequência da abordagem feita, na qual foi discutida a susceptibilidade que áreas declivosas apresentam à erosão e a importância da preservação da vegetação dessas áreas para controlar estes processos e promover a infiltração da água nestes locais, assim como nas margens dos cursos d’água, 
como fundamentais na manutenção do solo ali presente. Com isso, nos desenhos finais essas áreas foram representadas recobertas por árvores, o que deixa claro a assimilação pelos estudantes do papel da cobertura vegetal na preservação do solo. Sobre a abordagem referente à importância no ciclo hidrológico, os processos de infiltração e impermeabilização do solo não foram representados nos desenhos iniciais, e a existência do lençol freático apesar de presente, foi bem menos representada (Figura 13).

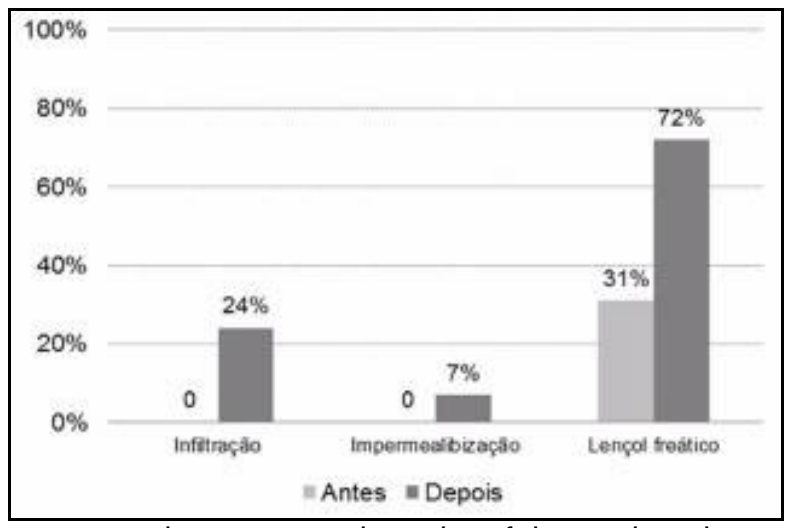

Figura 13: Análise comparativa entre os desenhos feitos pelos alunos antes e depois da oficina, verificando aspectos do solo relacionados ao ciclo hidrológico.

Fonte: Próprio autor (2013)

A presença destes itens nos desenhos indica, portanto, a assimilação desses conceitos, de tal forma que os alunos foram capazes de integrá-los dentro de seu contexto, e assim ilustrar sua importância na paisagem natural e ainda incluí-los de forma harmônica em processos de uso e ocupação, como pode-se verificar nos desenhos (Figura 14). Este fato foi considerado muito significativo uma vez que se tem como finalidade geral em todas as atividades do projeto a promoção de atitudes de educação ambiental.

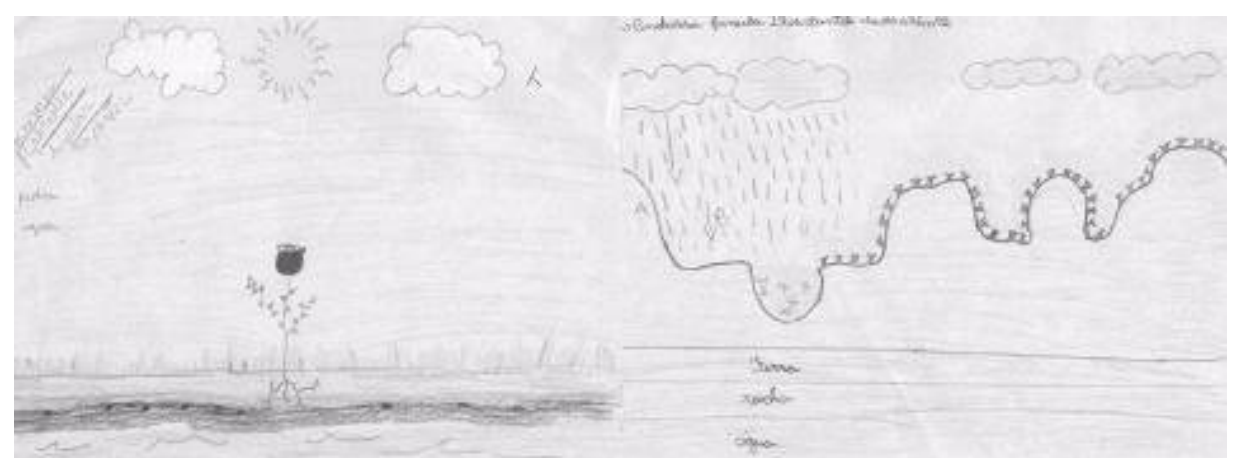

Figura 14: Desenhos elaborados por diferentes alunos depois de realizada a oficina em que foram representados elementos relacionados ao ciclo hidrológico. Fonte: Próprio autor (2013)

Em relação à prática de infiltração em diferentes solos, evidencia-se pelas respostas apresentadas nas perguntas existentes no roteiro (Anexo 2), que os objetivos foram alcançados na maioria dos itens. Dentre as perguntas, todos os grupos identificaram corretamente os tipos de solos e perceberam que 
o processo de infiltração é diferente em solos distintos, assim como foram capazes de trazer explicações pertinentes para o que observaram, como indicado nas respostas das perguntas por todos os grupos. Os estudantes demonstraram ainda entendimento sobre o papel da influência antrópica neste processo, pois ao serem perguntados "Que tipo de uso do solo pelo homem costuma atrapalhar nesse processo?", todos indicaram um tipo de uso antrópico (Asfalto, por exemplo). Apenas quando questionados sobre a relação com o ciclo hidrológico, os resultados empataram em $50 \%$ de acertos e erros, comparando-se a teoria apresentada com a resposta da pergunta "Por que é importante que a água penetre no solo? ", sendo que quando a resposta se encontrava de acordo com a teoria apresentada ela foi considerada correta, e que principalmente as respostas vazias foram consideradas incorretas. $O$ fato do índice de acerto à essa pergunta ter sido baixo pode ser atribuído a pouca ênfase que se deu a detalhes do ciclo hidrológico, de forma que não houve tempo hábil para trabalhar de modo mais detalhado suas etapas, por conta dos objetivos da oficina, que manteve o foco na temática solos, ficando essa parte incluída numa futura oficina de águas subterrâneas.

A pergunta final, feita sobre formas de favorecer o processo de infiltração no solo apesar da necessidade que temos de utilização do mesmo, foi feita com a finalidade de introduzir as questões ambientais sobre o tema solo e levar a reflexão sobre atitudes que podem ser tomadas individualmente, no sentido de preservação desse recurso.

As respostas dos estudantes, apesar das diferentes abordagens, podem ser compiladas em três temas centrais; segundo eles as formas de favorecer o processo de infiltração consistem principalmente em medidas que evitem a contaminação do solo (27,5\%) e a impermeabilização maciça $(27,5 \%)$. A maioria $(44,8 \%)$ sugeriu o reflorestamento como a medida mais importante na preservação dos solos e favorecimento do processo de infiltração.

Tais resultados são reflexos do trabalho com o uso das representações em pet das diferentes ocupações dos solos, como a impermeabilização, a manutenção da cobertura vegetal e a impermeabilização resultante da compactação. Outro ponto alto foi o trabalho com a maquete, no qual foi possível verificar consequências desses três tipos de processo: contaminação, desmatamento e impermeabilização.

Em vista disso, pode-se considerar satisfatória a abordagem dos alunos mais ainda pela inclusão desses processos em uma paisagem, fato surpreendente em algumas representações.

Nesta linha de atuação, até o momento tem-se a realização das oficinas descritas acima e estabelecidas parcerias com cinco escolas, sendo três pertencentes à rede estadual de ensino e as duas, já mencionadas, pertencentes à rede municipal. A inclusão de mais três escolas tem sido adiada por conta da demanda e dos compromissos assumidos nas escolas onde as atividades já iniciaram. 


\section{Oficinas para os educadores}

Quanto a segunda linha de atuação do projeto, referente a atuação junto aos educadores, é importante ressaltar que essa etapa se encontra ainda em fase inicial, com o levantamento das manifestações de interesse e ainda desenvolvendo o roteiro dos minicursos. Tal fato decorre da própria metodologia do projeto que pretende trabalhar de forma personalizada em cada unidade de ensino, de forma que a montagem dos minicursos é feita conforme o levantamento das necessidades dos discentes interessados em participar. Pretende-se com isso atender as necessidades específicas de cada escola, evitando-se uma abordagem que não se adeque a realidade daquele grupo e incentivando a participação dos discentes.

Quanto ao apoio a projetos, já se formalizou parcerias nas duas escolas participantes até agora, e percebe-se a crescente manifestação de interesse em escolas já incluídas no projeto, mesmo onde ainda não se realizou oficinas.

No entanto, quando se pensa de forma geral em todas as atividades do projeto, não se pode deixar de mencionar que a eficácia das atividades aplicadas de forma pontual torna-se bem menos eficiente que as atividades feitas nas escolas que abraçaram o projeto, estabelecendo uma parceria que garanta a continuidade das ações, mesmo após a finalização das atividades.

Tal fato foi constato por Curado e Angelini (2006) que avaliaram a eficiência de práticas de educação ambiental após dois e três anos de sua realização. Os autores verificaram que as atividades pontuais quando não acompanhadas e desenvolvidas dentro do ambiente formal de ensino, não conseguiram o efeito esperado, sendo, portanto, necessária a continuidade e inserção dessa temática dentro do cotidiano escolar.

É partindo dessa constatação que este projeto procurou trabalhar não apenas de forma pontual, mas atuando em vários níveis e procurando incluir todos os atores importantes no processo de ensino e aprendizagem, como já mencionado, fechando o ciclo universidade-educador-aluno, atuando juntos, pensando não apenas na sedimentação de conceitos mas na sensibilização suficiente para, mesmo de forma incipiente, promover uma mudança de atitude no sentido de formas mais sustentáveis de uso dos recursos naturais.

\section{Conclusão}

A utilização da metodologia de articulação de conteúdo permitiu que as oficinas fossem estruturadas com uma diversidade representativa de informações dentro do conjunto de temas com os quais o projeto pretende trabalhar, e levou a uma conexão entre os tópicos que confere às oficinas a apresentação do conhecimento de forma interligada e objetiva, fatores cruciais para atingir os objetivos pretendidos. 
Com a aplicação sucessiva das oficinas foi possível ressaltar o potencial das geociências na sensibilização em relação às questões ambientais, mesmo que nos primeiros resultados os conceitos técnicos tenham se apresentado como a maior dificuldade de assimilação, o que levou a reformulações da abordagem destes conceitos nas oficinas seguintes. Com isso, as respostas dos alunos quanto à compreensão do conteúdo teórico como um todo foi considerada satisfatória dentro do esperado, e a este fato atribui-se também o papel de atividades práticas e de experimentação, que se mostraram ferramentas de ensino muito úteis para a compreensão clara do conhecimento apresentado aos alunos.

No que diz respeito à mensagem a ser passada dentro dos princípios da educação ambiental, os resultados foram otimistas, pois indicam que a maioria das crianças entenderam a complexidade e importância das questões ambientais relativas aos temas desenvolvidos, e foram capazes de sugerir práticas de sustentabilidade aplicáveis ao cotidiano com base nos conteúdos trabalhados nas oficinas.

Tal cenário indica que o aprimoramento constante das oficinas tende a trazer resultados positivos, e diz também que o processo de sensibilização e reflexão sobre formas sustentáveis de interação com o ambiente tem sido alcançado, o que consolida as geociências como cenário de práticas de educação ambiental. Considera-se ainda que os resultados positivos verificados através das oficinas serão maximizados quando as etapas seguintes do projeto forem concretizadas, incluindo de fato a participação de outros atores do ambiente escolar, como a realização de minicursos com docentes, o que permite a continuidade das atividades dentro da instituição de ensino mesmo após o encerramento do projeto. É sobre estas perspectivas que se estabelecem as metas de continuidade do projeto a partir deste momento.

\section{Referências}

BACCI, D.L.C. A contribuição do conhecimento geológico para a educação ambiental. Pesquisa em Debate, ed. 11, v. 6, n. 2, 2009. Disponível em: <http://pesquisaemdebate.net/docs/pesquisaEmDebate 11/artigo 7.pdf> Acesso em 20 de junho de 2012;

BIONDI, D.; FALKOWSKI, V. Avaliação de uma atividade de educação ambiental com o tema "solo". Rev. eletrônica Mestr. Educ. Ambient, v. 22, 2009. Disponível em: <www.seer.furg.br/remea/article/download/2811/1593> Acesso em: 20 de junho de 2012; 
BRANDÃO, C. R. Pesquisa Participante. In Encontros e caminhos: Formação de Educadoras(es) Ambientais e Coletivos Educadores. Ministério do Meio Ambiente. Diretoria de Educação Ambiental. Luiz Antonio Ferraro Júnior (org.). Brasília: MMA/ Diretoria de educação Ambiental, p. 259-266, 2005;

BRASIL. Ministério da Educação (MEC), Secretaria de Educação Media e Tecnológica (SEMTEC). PCN+ Ensino Médio: orientações educacionais complementares aos Parâmetros Curriculares Nacionais - Ciências da Natureza, Matemática e suas Tecnologias. Brasília: MEC/SEMTEC, 2002;

CARNEIRO, C.D.R.; TOLEDO, M.C.M.; ALMEIDA, F.F.M.. Dez motivos para a inclusão de temas de geologia na educação básica. Revista Brasileira de Geociências, v.34, p. 553-560, 2004.

COMPIANI, M.; GONÇALVES, P.W. Epistemologia e Historia de La Geologia como fuentes para la seleccion y organizacion del curriculum. Enseñanza de lãs Ciências de La Tierra, Vol. IV(1), 38-45, 1996;

CURADO, P. M \& ANGELINI, M. R. Avaliação de atividade de educação ambiental em trilha interpretativa, dois a três anos após sua realização. Acta Sci. Biol. Sci: Maringá, v. 28, n. 4, p. 395-401, 2006. Disponível em: $<$ http://periodicos.uem.br/ojs/index.php/ActaSciBiolSci/article/viewFile/174/240> Acesso em: 15 de junho de 2012;

GONZALEZ, L.T.V, et al. Educação ambiental na comunidade: uma proposta de pesquisa-ação. Rev. eletrônica Mestr. Educ. Ambient, v.18, 2007;

SCHIEL, D. \& FREITAS, D. Instrumentação para o ensino interdisciplinar das ciências da natureza e da matemática. CDCC - USP, 2002. Disponível em: <http://www.cdcc.usp.br/exper/medio/index.htm> Acesso em: 15 de junho de 2012. 